Travmatik diş

yaralanmalarında

ilkokul öğretmenlerinin

bilgi düzeyleri ve

tutumlarının

belirlenmesi ve

öğretmenlere verilen

öğretici broşürün

etkisinin

değerlendirilmesi

\section{Determining the level of knowledge and attitudes of elementary school teachers in traumatic dental injuries and evaluation of the effect of educational leaflet for teachers}

\author{
Dr. İbrahim Şimşek \\ Başçiftlik Illçe Devlet Hastanesi, Tokat
}

Doç. Dr. Buket Ayna

Dicle Üniversitesi, Diş Hekimliği Fakültesi, Çocuk Diş Hekimliği A.D., Diyarbakır

Yrd. Doç. Dr. Ersin Uysal

Dicle Üniversitesi, Diyarbakır Teknik Bilimler Meslek Yüksekokulu, Diyarbakır

Geliş tarihi: 14 Mart 2017

Kabul tarihi: 3 Nisan 2017

DOI: 10.5505/yeditepe.2017.30922

\section{Yazışma Adresi:}

Doc. Dr. Buket Ayna

Dicle Üniversitesi, Diş Hekimliği Fakültesi, Çocuk Diş Hekimliği AD. Diyarbakır.

Tel: 00904122488101-06

Fax: 00904122488100

E-posta: buketayna@hotmail.com
ÖZET

Amaç: Diyarbakır ilinde görev yapan ilkokul öğretmenlerinin travmatik diş yaralanmaları (TDY) karşısındaki tutumlarının ve kişisel tecrübelerinin değerlendirilmesi, bilgi düzeylerinin ölçülmesi ve hazırlanan öğretici broşürlerle, öğretmenlere diş yaralanmalarının ardından yapacakları ilk müdahalelerle dişin iyileşme sürecine katkı sağlayabilecekleri bilincinin yerleştirilmesidir.

Gereç ve yöntem: Çalışmamıza Diyarbakır il merkezindeki 34 ilkokulda görev yapmakta olan 1224 ilkokul öğretmeni dahil edilmiştir. Katıımcı öğretmenlere dört bölümden oluşan TDY konusunda sorular içeren anket formaları dağıtılıp cevaplamaları istenmiştir. Anket sorularının cevaplanması bittikten sonra öğretmenlerin konu hakkındaki bilgi seviyesini artırmak amacıyla hazırladığımız öğretici broşürler teslim edilmiş ve iki hafta sonra öğretmenlerin aynı anket sorularını tekrar cevaplamaları sağlanmıştır.

Bulgular: Öğretmenlere yöneltilen anket sonucunda 1 . bölümde katılımcı öğretmenlerin kişisel bilgileri değerlendirilmiştir. Cinsiyetin, yaşın ve meslekte hizmet süresinin bilgi düzeyini etkilediği görülmüştür. Bilgi düzeyinin uygulanan öğretici broşürün etkisi ile her parametrede anlamlı bir şekilde arttığı tespit edilmiştir. Íkinci bölümde öğretmenlerin TDY karşısındaki tutumları değerlendirilmek istenmiş ve öğretici broşürlerin etkisi ile alınan cevaplarda anlamlı bir farklıık olduğu görülmüştür. Kişisel tecrübe ve kendini değerlendirme başlıklı 3. bölümde öğretmenlerin \%60'ı daha önce diş yaralanması gördüğünü belirtmiştir ve görülen bu yaralanmaların \%36,7'sinin küçük bir kırık olduğu öğrenilmiştir. Katılımcı öğretmenlerin \%48,6'sı TDY sonrası ilk başvuracakları birimi "Diş hastanesi" cevabı ile belirtmişlerdir. TDY'deki bilgi düzeyini ölçmeyi amaçlayan 4. bölümde ise öğretici broşürlerin etkisi ile tüm vaka değerlendirmelerinde bilgi düzeyinde anlamlı bir artış gözlemlenirken sadece süt dişi avülsiyonuna yönelik yöneltilen soru için anlamlı bir farklıık gözlenmemiştir.

Sonuç: Çalışmanın sonuçları değerlendirildiğinde elde edilen veriler Diyarbakır'daki ilkokul öğretmenlerinin TDY konusundaki bilgi düzeylerinin hazırlanan broşürler öncesinde yeterli olmadığını göstermektedir. Bununla birlikte öğretici broşürlerin etkisi ile elde edilen sonuçlar ümit vericidir.

Anahtar kelimeler: Dental travma, öğretmen, bilgi düzeyi.

\section{SUMMARY}

Aim: Evaluation of the personal experience and attitudes of primary school teachers who served in Diyarbakır at traumatic dental injuries, to measure the level of knowledge, to impose consciousness of contribution to healing process with first-aid at dental injuries to teachers by prepared informative brochures.

Materials and Methods: In our study we included 1224 primary school teachers who are working at 34 schools in Diyarbakır. First of all the purpose of study was told to the par- 
ticipant teachers. After that survey form about traumatic dental injuries distrubited to all of them and wanted to get answer to their survey forms. After finish their survey forms answers, to increase level of knowledge about this subject, the brochures were delievered to teachers and wanted to get answers the same survey forms two weeks later.

Results: At the first part of survey, participant teachers answered about their personal informations. Gender, age and time at the service has been shown to affect the level of knowledge. However, the effect of each parameter with applied tutorial leaflet has also been found to be increased in a meaningful way. In the second part the attitudes of teachers traumatic tooth injuries were evaluated and Tutorial on the responses received to the effect of the leaflet was found to be a significant difference. Personal experience and self-evaluation in the third chapter titled of teachers stated that $60 \%$ of dental injuries seen before. In response to the question of the type of injury most questionable with a rate of $36.7 \%$ "It was a small fracture". Participant teachers \% 48.6 will apply for the first unit after a traumatic dental injury "Dental hospital" stated the answer. At the 4th part, In all cases a significant increase in knowledge instructive assessment of the effects observed when leaflets were not observed a significant difference to the questions posed for milk tooth avulsion.

Conclusion: The data obtained when evaluating the results of the study before prepared brouchers of knowledge on dental trauma primary school teachers in Diyarbakir shows that is not enough. However the results obtained by the effect of the informative brochure are promising.

Key words: Dental trauma, teacher, knowledge.

\section{GíRiş}

Travmatik Dental Yaralanma (TDY) bireyler üzerinde estetik, fonksiyonel ve psikolojik olarak olumsuz sonuçları olan bir toplum-ağız-diş sağlığı sorunudur., ${ }^{1,2}$ TDY yaşamın her döneminde meydana gelebildiği gibi çocukların bu yaralanmalara daha sık maruz kaldığı bilinmektedir. Çocukluk çağında sıklıkla görülen diş çürükleri ve kayıplarında koruyucu diş hekimliği uygulamalarının yaygınlaşması sonucu azalma görülmesine rağmen, yapılan çalışmalar TDY'nin halen kontrolü sağlanamayan bir sorun olarak devam ettiğini göstermektedir. ${ }^{3,4}$

ilkokul çağındaki çocukların yaşları ve okullarda geçirdikleri uzun süreler nedeniyle travma sonucu meydana gelen diş yaralanmalarının büyük bir kısmı okullarda gerçekleşmektedir. Norveç'te yapılan bir çalışmada, travma hikayesi bulunan 1275 kişinin \%48'inde TDY'nin okulda meydana geldiği bildirilmiştir. Bu yaralanmalar çocukların ağız sağlıklarının yanı sıra, onları fiziksel ve psikolojik olarak da etkilemektedir. ${ }^{5}$
TDY'de kron kırıklarında kııı parçanın bulunması veya avülsiyona uğrayan dişlerin uygun ortamda taşınması gibi erken ve doğru ilk müdahale ilgili dişin prognozu açısından son derece önemlidir. ${ }^{3} \mathrm{Bu}$ amaç doğrultusunda öğretmenlere verilecek eğitim ile hızlı ve etkin müdahale okulda yapılabilecek ve hastaların zaman ve maddi kayıpları en aza indirgenecektir.

Meydana gelebilecek yaralanmalardan korunma ve yaralanma sonrası olabilecek riskler hakkında toplumun bilgilendirilmesi amacıyla öncelikle bilgi sahibi olmaları gereken ebeveyn ve öğretmenlere yönelik olarak çalışmalar yapılsa da henüz bu konu toplum sağlığı kampanyalarında yüksek önceliğe sahip değildir. ${ }^{1-3}$ Konu ile ilgili birçok çalışmada öğretmenlerin TDY hakkındaki bilgi düzeylerinin çok düşük olduğu görülmüştür.6-9 Ülkemizde yapılmış olan az sayıdaki çalışmada da durum benzer şekildedir. ${ }^{10,11}$

Bu bilgilere paralel olarak çalışmamızın amacl; Diyarbakır ilinde görev yapan ilkokul öğretmenlerinin travmatik diş yaralanmaları karşısındaki tutumlarının ve kişisel tecrübelerinin değerlendirilmesi, bilgi düzeylerinin ölçülmesi ve hazırlanan öğretici broşürlerle, öğretmenlere diş yaralanmalarının ardından yapacakları ilk müdahalelerle dişin iyileşme sürecine katkı sağlayabilecekleri bilincinin yerleştirilmesidir.

\section{GEREÇ VE YÖNTEM}

Çalışmamız Diyarbakır il merkezindeki 34 ilkokulda görev yapmakta olan ve çalışmaya dahil olmayı kabul eden 1224 öğretmen ile yarı-deneysel olarak yapılmıştır. Bu çalışmada yarı-deneysel yöntemlerden biri olan "Tek Grupta Ön Test-Son Test Modeli" kullanılmıştır.

Veri toplama aracı amacıyla oluşturulan anket formu, TDY'de acil müdahalede önemli olan temel konular hakkında öğretmenlerin bilgi seviyelerini ve tutumlarını belirlemek amacıyla çoktan seçmeli sorular olarak hazırlanmiştır (Ek 1).

Anket formaları daha önce benzer konularda yapılmış çalışmalarda kullanılmış geçerliliği test edilmiş sorular kullanılarak oluşturulmuştur. 9,11,12

Anket toplam 4 bölümden oluşmaktadır. İlk bölümde öğretmenlerin kişisel bilgileri, 2. bölümde TDY karşısındaki tutumları, 3. bölümde kişisel tecrübeleri sorgulanmıştır. Son bölüm olan 4. bölümde ise okullarda olabilecek şekilde anlatılan vakalar resimlerle de tanımlanıp, öğretmenlerin bilgi düzeyleri saptanmaya çalışılmıştır. Bu bölümdeki sorularda şıklara verilen cevaplar; 'yanlış cevap' 0 puan, 'kabul edilebilir cevap' 1 puan ve 'ideal cevap' 2 puan olarak değerlendirilmiştir.

Çoktan seçmeli olarak hazırlanan soruların çoğu tek doğru cevaptan oluşurken, bazı soruların seçenekleri arasında ideal ve kabul edilebilir cevap olmak üzere iki doğru cevap bulunmaktadır. Bulunan verilerin tablo üzerinden 
değerlendirilmesi yapılırken hesaplama karmaşası yaşanmaması adına yalnızca ideal cevap verme oranlarında meydana gelen değişimler yorumlanmıştır. Fakat puan ortalaması grafikleri kabul edilebilir cevabında değerlendirmeye katılabilmesi adına, ideal ve kabul edilebilir cevapların ortalamaları baz alınarak hazırlanmıştır.

Çalışmamızda ilk uygulanan ön testle; öğretmenlerin travmatik diş yaralanmalarında acil durum yönetimi konusundaki bilgi düzeyi ve tutumlarının belirlenmesi amaçlanmıştır. ön testlerin öğretmenlerden toplanılmasının ardından katıımcılara hazırladığımız "Çocuklarda TDY ve Acil Müdahale" başlıklı broşürler dağıtıımıştır. Hazırlanan son test, broşürün ayrıntılı olarak incelenebilmesi ve etkilerinin değerlendirilebilmesi amacıyla 2 hafta sonra uygulanmıştır. Son testin uygulanmasıyla konu hakkında hazırladığımız öğretici broşürün (Ek 1) öğretmenlerin TDY hakkında oluşan bilgi seviyelerine etkisini değerlendirmek amaçlanmıştır.

İstatistik analiz testlerinde \%95'lik güven aralığı uygulanmış olup; $p<0,05$ için sonuçlar istatistiksel olarak anlamlı kabul edilmiştir. Gruplar arası iki ortalamanın farklarının araştırılmasında Independent Students' t, frekans dağılımları için istatistiksel çıkarımlarda Ki-kare, yaş gruplarına göre ortalama değerlerinin karşılaştııılmasında One Way Anova (ANOVA) testleri kullanıldı. İstatistiksel anlamlıık söz konusu olduğunda farklılığın hangi gruplardan kaynaklandığını belirlemede Tukey-HSD çoklu karşılaştırma testi uygulandı. Aynı zamanda istatistiksel hesaplamalarda Power Analiz değerlendirmesi de yapıldı.

\section{BULGULAR}

\section{Bölüm I: Kişisel Bilgiler}

Öğretmenlere yöneltilen anket sonucunda kişisel bilgilerin olduğu Bölüm I'den elde edilen veriler Tablo 1'de görülmektedir.

Tablo 1: Katılımcı öğretmenlerin kişisel bilgileri.

\begin{tabular}{|l|c|c}
\hline & $\mathrm{n}$ & $\%$ \\
\hline Cinsiyet & 636 & 52 \\
Erkek & 588 & 48 \\
Kadın & & \\
\hline Yass & 208 & 17 \\
$20-30$ & 409 & 40 \\
$30-40$ & 527 & 43 \\
$>40$ & & \\
Meslekte hizmet süresi & 193 & 16,20 \\
$1-5$ & 163 & 13,30 \\
$6-10$ & 863 & 70,50 \\
$>11$ & & \\
\hline Daha önce ilk yardım kursu aldınız mı? & 449 & 36,70 \\
Evet & 775 & 63,30 \\
Hayır & & \\
\hline Yukarıdaki soruya cevabınız evet ise aldığınız kurs \\
"travmatik diş yaralanmalarında acil durum" konusunu \\
içeriyor muydu? & 42 & 3,40 \\
Evet & 1182 & 96,60 \\
Hayır & & \\
\hline
\end{tabular}

Ankete katılan öğretmenlerin uygulanan ön teste verdikleri cevapların puan ortalamaları, öğretici broşürün 2 hafta süreyle öğretmenlerde kalmasını takiben yapılan Son Testte istatistiksel olarak anlamlı bir artış göstermiştir $(p=0,00)$ (Tablo2).
Tablo 2: Ön Testte ve Son Testte alınan cevapların toplam puan ortalamalarına ait tanımlayıcı istatistik değerleri $(* \mathrm{p}=0.00)$.

\begin{tabular}{|l|c|c|c|c|c|c|}
\hline & $\mathbf{n}$ & Ortalama & Minimum & Maksimum & $\begin{array}{c}\text { Std. } \\
\text { Sapma }\end{array}$ & p \\
\hline $\begin{array}{l}\text { Puan } \\
\text { (Ön Test) }\end{array}$ & 1224 & 9,92 & 1,00 & 23,00 & 3,70 & \multirow{2}{*}{$* 0.00$} \\
\cline { 1 - 5 } $\begin{array}{l}\text { Puan } \\
\text { (Son Test) }\end{array}$ & 1224 & 18,25 & 3,00 & 24,00 & 4,03 & \\
\hline
\end{tabular}

Cinsiyetin, yaşın ve meslekte hizmet süresinin bilgi düzeyini istatistiksel olarak anlamlı şekilde etkilediği $(p<0,05)$ görülürken; ilk yardım kursu alanlar ve almayanlar arasında istatistiksel bir fark olmadığı $(p>0,05)$ tespit edilmiştir. Bunun yanında, bilgi düzeyinin uygulanan öğretici broșürün etkisi ile her parametrede istatistiksel olarak anlamlı şekilde arttığı görülmüştür (Tablo 3).

Tablo 3: Öğretmenlerin Ön Testte ve Son Testte alınan cevapların toplam puan ortalamalarının cinsiyete, yaş aralıklarına, meslekte hizmet süresine ve TDY'de ilk yardım konusunda kurs alma durumlarına göre değerlendirilmesi $(* p<0,05)$.

\begin{tabular}{|c|c|c|c|c|c|}
\hline & Cinsiyet & $\mathbf{n}$ & Ortalama & Std. Sapma & $\mathbf{p}$ \\
\hline \multirow{2}{*}{$\begin{array}{l}\text { Puan } \\
\text { (Ön Test) }\end{array}$} & Erkek & 636 & 9,68 & 3,83 & \multirow{4}{*}{$* 0.05$} \\
\hline & Kadın & 588 & 10,17 & 3,55 & \\
\hline \multirow{3}{*}{$\begin{array}{l}\text { Puan } \\
\text { (Son Test) }\end{array}$} & Erkek & 636 & 18,23 & 4,01 & \\
\hline & Kadın & 588 & 18,28 & 4,04 & \\
\hline & Yaș aralığı & $\mathbf{n}$ & Ortalama & Std. Sapma & $\mathbf{p}$ \\
\hline \multirow{3}{*}{$\begin{array}{l}\text { Puan } \\
\text { (Ön Test) }\end{array}$} & $20-30$ & 208 & 8,87 & 3,31 & \multirow{6}{*}{${ }^{*} 0.05$} \\
\hline & $30-40$ & 489 & 9,95 & 3,64 & \\
\hline & 40'dan fazla & 527 & 10,29 & 3,84 & \\
\hline \multirow{3}{*}{$\begin{array}{l}\text { Puan } \\
\text { (Son Test) }\end{array}$} & $20-30$ & 208 & 17,18 & 4,13 & \\
\hline & $30-40$ & 489 & 18,53 & 3,88 & \\
\hline & 40'dan fazla & 527 & 18,49 & 4,02 & \\
\hline & Hizmet süresi (Yıl) & $\mathbf{n}$ & Ortalama & Std. Sapma & $\mathbf{p}$ \\
\hline & $1-5$ & 228 & 8,98 & 3,38 & \multirow{6}{*}{$*_{0.05}$} \\
\hline Puan & 6-10 & 152 & 9,96 & 3,48 & \\
\hline & 11'den fazla & 844 & 10,12 & 3,79 & \\
\hline \multirow{4}{*}{$\begin{array}{l}\text { Puan } \\
\text { (Son Test) }\end{array}$} & $1-5$ & 228 & 17,35 & 4,05 & \\
\hline & 6-10 & 152 & 18,02 & 4,31 & \\
\hline & 11 'den fazla & 844 & 18,54 & 3,93 & \\
\hline & $\begin{array}{l}\text { TDY'de ilk yardım } \\
\text { konusunda kurs } \\
\text { aldınz mı? }\end{array}$ & $\mathbf{n}$ & Ortalama & Std. Sapma & $\mathbf{p}$ \\
\hline \multirow[b]{2}{*}{ Ön Test } & Evet & 42 & 9,69 & 3,02 & \multirow{4}{*}{0,06} \\
\hline & Hayir & 1182 & 9,92 & 3,73 & \\
\hline \multirow[b]{2}{*}{ Son Test } & Evet & 42 & 17,14 & 3,79 & \\
\hline & Hayir & 1182 & 18,29 & 4,03 & \\
\hline
\end{tabular}

\section{Bölüm II: Tutumlar}

Bu bölümdeki tüm sorulara alınan cevaplarda verilen eğitim sonrası istatistiksel olarak anlamlı bir değişiklik meydana gelmiştir $(p<0,05)$ (Tablo 4).

Tablo 4: Öğretmenlerin TDY karşısındaki tutumlarına ait tanımlayıcı istatistik değerleri $(* \mathrm{p}<0,05)$

\begin{tabular}{|c|c|c|c|c|c|c|c|c|c|c|c|c|c|}
\hline & \multicolumn{6}{|c|}{ ÖN TEST } & \multicolumn{6}{|c|}{ SON TEST } & \multirow[b]{3}{*}{$\mathrm{p}$} \\
\hline & \multicolumn{2}{|c|}{ Kathlyorum } & \multicolumn{2}{|c|}{ Katilmiyorum } & \multicolumn{2}{|c|}{ Kararsızım } & \multicolumn{2}{|c|}{ Kattlyyorum } & \multicolumn{2}{|c|}{ Katılmıyorum } & \multicolumn{2}{|c|}{ Kararsinm } & \\
\hline & n & $\%$ & $\mathbf{n}$ & $\%$ & $\mathbf{N}$ & $\%$ & $\mathbf{n}$ & $\%$ & $n$ & $\%$ & $\mathbf{n}$ & $\%$ & \\
\hline Soru 1 & 137 & 11,19 & 896 & 73,20 & 191 & 15,6 & 160 & 13,07 & 1008 & 82,35 & 56 & 4,57 & \\
\hline Soru 2 & 1097 & 89,62 & 41 & 3,35 & 86 & 7,02 & 1146 & 93,62 & 50 & 4,08 & 28 & 2,28 & \\
\hline Soru 3 & 434 & 35,45 & 472 & 38,56 & 318 & 25,98 & 258 & 21,07 & 812 & 66,34 & 154 & 12,50 & $* 0,05$ \\
\hline Soru 4 & 905 & 73,94 & 148 & 12,09 & 171 & 13,97 & 1038 & 84,80 & 104 & 8,50 & 82 & 6,70 & \\
\hline Soru 5 & 991 & 80,96 & 127 & 10,37 & 106 & 8,66 & 1112 & 90,85 & 76 & 6,20 & 36 & 2,94 & \\
\hline
\end{tabular}

\section{Bölüm III: Kișisel Tecrübe Ve Kendini Değerlendirme}

Çalışmaya katılan öğretmenlerin \%60'ı daha önce diş yaralanması gördüğünü belirtmiştir. Yaralanmanın tipinin sorgulandığı soruya cevap olarak \%36,7 ile "Küçük diş kırıkları" yanıtı alınmıştır. Katıımcı öğretmenlerin \%48,6'sı TDY sonrası ilk başvuracakları birimi "Diş Hastanesi" cevabı olarak belirtmişlerdir. 
Bölüm IV: Travmatik Diş Yaralanmalarında Bilgi Düzeyi Vaka I: Dişte Sallanma

Öğretmenlere "Dişte Sallanma" başlığı altında yöneltilen soruya ön testte "Veliyi olayla ilgili bilgilendirip diş hekimine yönlendiririm" cevabını veren öğretmen sayısı 810 $(\% 66,10)$ iken Son Testte bu sayı $1052(\% 85,90)$ olarak tespit edilmiştir $(p=0,00)$ (Tablo 5). Bu soruda elde edilen veriler sonucu oluşan puan ortalamasındaki artış Grafik 1 'de görülmektedir $(p=0,00)$.

Tablo 5: Vaka l'in ön test ve son test cevaplarına ait veriler $(* \mathrm{p}=0.00)$

\begin{tabular}{|l|c|c|c|c|c}
\hline \multirow{2}{*}{} & \multicolumn{2}{|c|}{ Ön Test } & \multicolumn{2}{c|}{ Son Test } & \\
\cline { 2 - 5 } & $\mathbf{n}$ & $\mathbf{\%}$ & $\mathbf{n}$ & $\mathbf{\%}$ & \multirow{2}{*}{$\mathbf{p}$} \\
\hline Cevap a & 323 & 26,30 & 156 & 12,70 & \multirow{2}{*}{$* 0,00$} \\
\hline Cevap b & 810 & 66,10 & 1052 & 85,90 & \\
\hline Cevap c & 91 & 7,40 & 16 & 1,30 & \\
\cline { 1 - 5 }
\end{tabular}

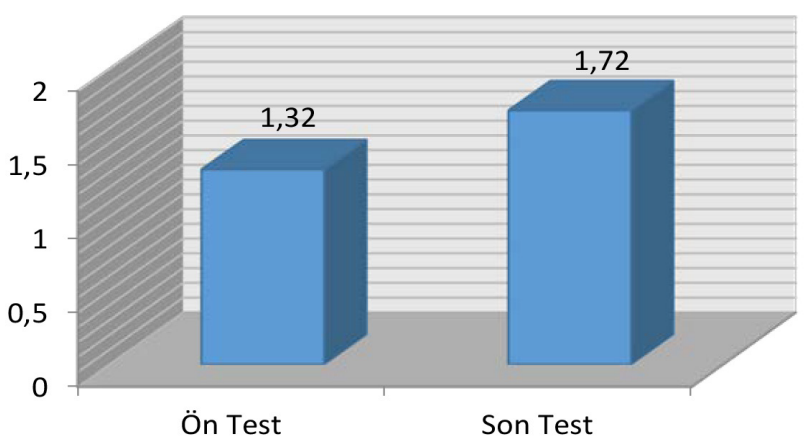

Grafik 1. Vaka I için ön test ve son test sonucu oluşan öğretmenlerin bilgi seviyelerine ait puan ortalaması değişimi

\section{Vaka II: Dişin Kırılması}

Öğretmenlere bu bölümde yöneltilen ilk soruda diş kırıklarında ayrılan parçanın bulunması gerektiğini düşünenlerin sayısı 615 (\%50,20)'den 1084 (\%88,60)'e yükselmiştir $(p=0,00)$. Bölümün ikinci sorusunda ise iki doğru cevaptan birisi olan ideal cevabı yani "c" şıkkını işaretleyenlerin sayısı 309 (\%25,20)'dan 770 (\%62,90)'e yükselmiştir $(p=0,00)$ (Tablo 6). Vaka II için öğretmenlerin bilgi seviyesine ait değişim Grafik 2'de görülmektedir $(p=0,00)$.

Tablo 6: Vaka II'nin ön test ve son test cevaplarına ait veriler $(* p=0.00$

\begin{tabular}{|c|c|c|c|c|c|c|}
\hline & \multicolumn{2}{|c|}{ Ön Test } & \multicolumn{2}{|c|}{ Son Test } & \multirow[b]{2}{*}{$\mathbf{P}$} \\
\hline & & $\mathrm{n}$ & $\%$ & $\mathbf{n}$ & $\%$ & \\
\hline \multirow[t]{2}{*}{ Soru 1} & Cevap a & 615 & 50,20 & 1084 & 88,60 & \multirow{2}{*}{$* 0.00$} \\
\hline & Cevap b & 609 & 49,80 & 140 & 11,40 & \\
\hline \multirow{4}{*}{ Soru 2} & Cevap a & 239 & 19,50 & 14 & 1,14 & \multirow{4}{*}{$* 0.00$} \\
\hline & Cevap b & 619 & 50,50 & 422 & 34,40 & \\
\hline & Cevap c & 309 & 25,20 & 770 & 62,90 & \\
\hline & Cevap d & 64 & 5,20 & 18 & 1,47 & \\
\hline
\end{tabular}

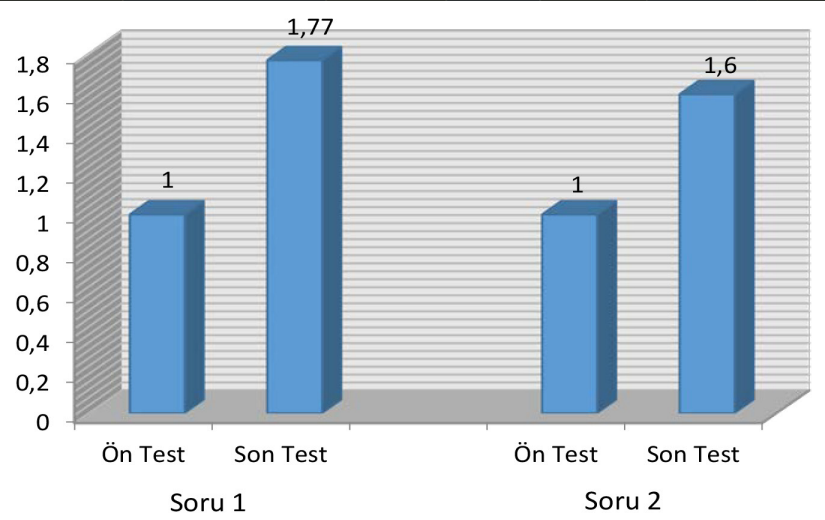

Grafik 2. Vaka II için ön test ve son test sonucu oluşan öğretmenlerin bilgi seviyelerine ait puan ortalaması değişimi

\section{Vaka III: Dişin Yer Değiştirmesi}

Öğretmenlere "Dişin Yer Değiştirmesi" ile ilgili bir olgunun tanımlanıp sorgulandığı vakada ön testte ideal cevap olan "b" seçeneğini işaretleyenler $98(\% 8,00)$ kişi iken son testte bu oran 740'a $(\% 60,45)$ yükselmiştir $(p=0,00)(T a b-$ lo 7). Bu soruda elde edilen veriler sonucu oluşan puan ortalamasındaki artış Grafik 3'de görülmektedir $(p=0,00)$.

Tablo 7: Vaka III'ün ön test ve son test cevaplarına ait veriler $(* \mathrm{p}=0.00)$

\begin{tabular}{|l|c|c|c|c|c|}
\hline & \multicolumn{2}{|c|}{ Ön Test } & \multicolumn{2}{c|}{ Son Test } & \multirow{2}{*}{ p } \\
\cline { 2 - 5 } & n & \% & n & \% & \multirow{2}{*}{$* 0.00$} \\
\cline { 1 - 5 } Cevap a & 86 & 7,02 & 4 & 0,32 & 60,45 \\
\cline { 1 - 5 } Cevap b & 98 & 8,00 & 740 & 37,74 & \\
\cline { 1 - 4 } Cevap c & 882 & 72,05 & 462 & 1,47 & \\
\hline
\end{tabular}

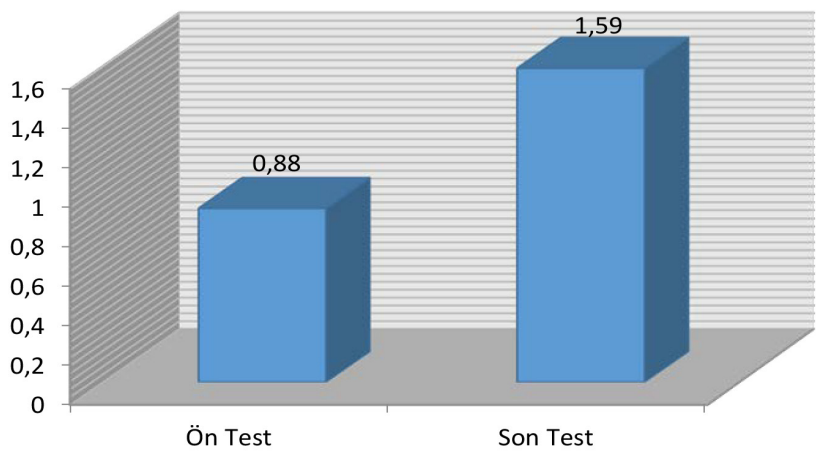

Grafik 3. Vaka III için ön test ve son test sonucu oluşan öğretmenlerin bilgi seviyelerine ait puan ortalaması değişimi

\section{Vaka IV: Dişin Tamamen Yerinden Çıkması}

Bölümün ilk sorusunda yaralanma anında yapılacak ilk müdahale sorgulanmıştır. Ön test sonucu katıımcı öğretmenlerden ideal cevap olan "Dişi bulmaya çalışııım" seçeneğini işaretleyen öğretmen sayısı yalnızca 91 $(\% 7,40)$ iken broşür dağıtımını takiben uygulanan Son Test'te bu sayı $732(\% 59,80)^{\prime}$ ye yükselmiştir $(p=0,00)$. İkinci soruda katılımcı öğretmenlerin dişi bulmaları halinde neresinden tutacağı sorgulanmıştır. Ön test sonucu katıımcı öğretmenlerden ideal cevap olan "Görünen yüzeyinden" seçeneğini işaretleyen öğretmen sayısı $611(\% 49,90)$ iken broşür dağıtımını takiben uygulanan son testte bu sayı $1048(\% 85,60)^{\prime}$ e yükselmiştir $(p=0,00)$. Üçüncü soruda katıımcı öğretmenlerin böyle bir yaralanma anında dişi yerine yerleştirip yerleştiremeyeceği sorgulanmıştır. Ön test sonucu dişi yerine yerleştirebileceğini düşünen öğretmen sayısı sadece $156(\% 12,70)$ iken broşür dağıtımını takiben uygulanan son testte bu sayı $666(\% 54,40)^{\prime}$ ya yükselmiştir $(p=0,00)$. Dördüncü soruda katılımcı öğretmenlerin dişi tekrar yerine yerleştirmeden önce hangi temizleme prosedürlerini uygulayacakları sorgulanmıştır. İdeal cevap olarak kabul edilen "Dişi akan su altında ovalamadan temizler ve yerine yerleştiririm" yanıtını verenler 415 (\%33,90) kişiden 1060 (\%86,60) kişiye yükselmiştir $(p=0,00)$. Beşinci soruda katılımcı öğretmenlerin dişi yerleştiremeyecekleri durumda hangi saklama koşulunda diş hekimine ulaşımını sağlayacakları sorgulanmıştır. İdeal cevaplardan biri olarak kabul edilen "Çocuğun kendi tükürüğü içinde" yanıtını veren- 
ler $98(\% 8,00)$ kişiden $510(\% 41,60)$ kişiye yükselmiştir. Diğer ideal cevap olan "Taze süt içinde" yanıtını verenler ise $55(\% 4,50)$ kişiden $198(\% 16,10)$ kişiye yükselmiştir. Her iki cevap içinde tespit edilen bu farklılık istatistiksel olarak anlamlıdır $(p=0,00)$. Altıncı soruda böyle bir travma anında dişin yerinden çıktıktan sonra en uygun ne kadar zaman içinde yerleştirilmesi gerektiği sorgulanmıştır. Ön test sonucu dişi tekrar yerine yerleştirme zamanı olarak ideal cevap olan "Hemen" yanıtını veren öğretmenler 299 $(\% 24,40)$ kiși iken bu sayı Son testte $834(\% 68,10)^{\prime}$ 'e yükselmiştir $(p=0,00)$. Yedinci soruda katılımcı öğretmenlerin olası yaralanma durumlarında süt dişleri ve daimi dişleri birbirinden ayırt edip edemeyecekleri sorgulanmıştır. Süt dişi ve daimi dişleri birbirinden ayırt edebileceğini düşünen öğretmen sayısı ön test sonucunda $601(\% 49,10)$ kişi iken Son testte bu sayı 754 (\%61,60)'e yükselmiştir $(p=0,00)$. Sekizinci soruda süt dişlerinin yerinden çıktığı yaralanmalarda yerine yerleştirip yerleştirmeyecekleri sorgulanmıştır. Süt dişlerinin yerine tekrar yerleştirilmemesi gerektiğini düşünen öğretmen sayısı ön test sonucunda $996(\% 81,40)$ kişi, son testte $1000(\% 81,70)$ kişi olarak tespit edilmiştir. Tespit edilen bu farklılık istatistiksel olarak anlamlı değildir ( $p>0,05)$ (Tablo 8). Vaka IV için elde edilen veriler sonucu oluşan puan ortalamalarındaki artışlar Grafik 4'de görülmektedir.

Tablo 8: Vaka IV'ün ön test ve son test cevaplarına ait veriler $(* \mathrm{p}=0.00)$

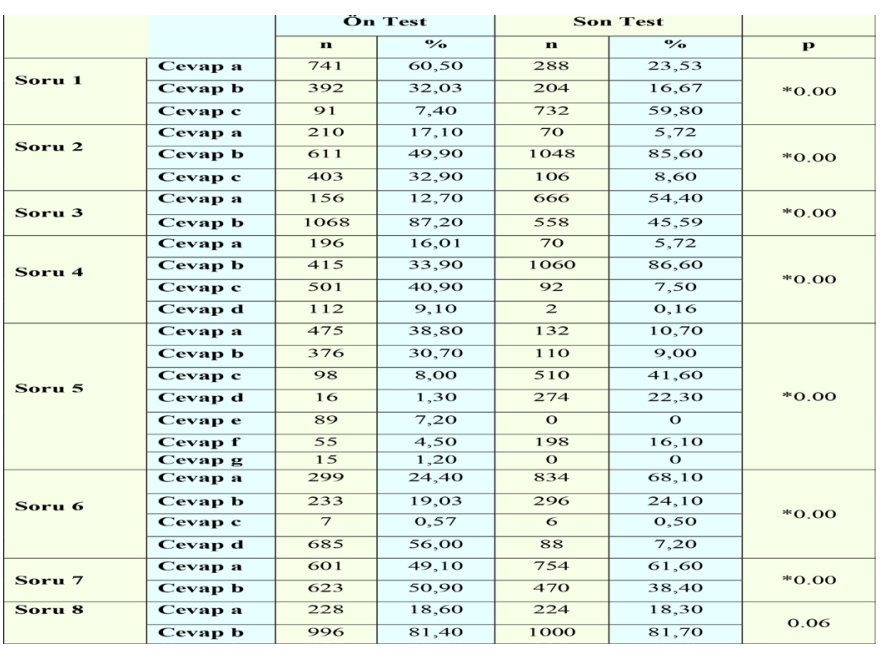

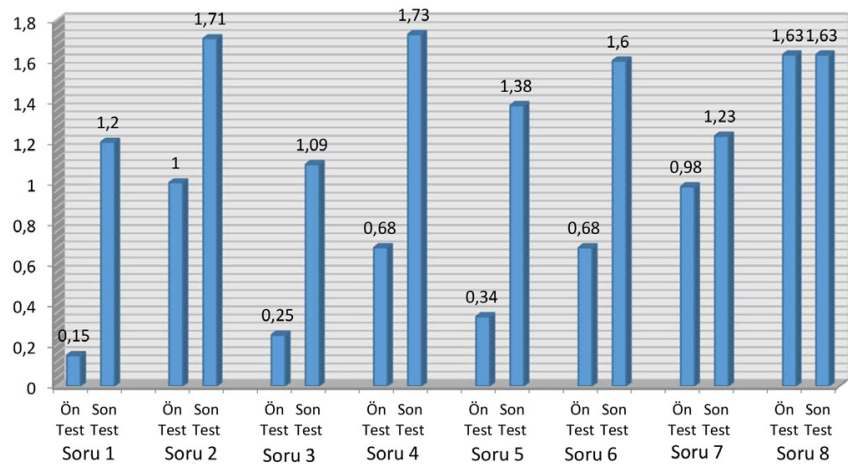

Grafik 4. Vaka IV için ön test ve son test sonucu oluşan öğretmenlerin bilgi seviye lerine ait puan ortalaması değişimi

\section{TARTIŞMA}

TDY yaşamın her döneminde meydana gelebildiği gibi çocukların bu yaralanmalara daha sık maruz kaldığı bilinmektedir. ${ }^{13,14}$ illkokul çağındaki çocukların yaşları ve okullarda geçirdikleri uzun süreler nedeniyle travma sonucu meydana gelen diş yaralanmalarının büyük bir kısmı okullarda gerçekleşmektedir. ${ }^{5}$ Kron kırıklarında kırık parçanın bulunması veya avülsiyona uğrayan dişlerin uygun ortamda taşınması gibi travmaya uğrayan bir dişe yapılacak doğru ve hızlı bir acil müdahale dişin prognozunu önemli ölçüde etkilemektedir. Aksi halde uygulanacak tedavi prosedürleri daha zor ve masraflı bir hale gelebilmektedir. Öğretmenlerin bilgi seviyelerini arttırmak amacıyla yapılmış olan çalışmalarda bilgi aktarıcı yöntem olarak ders anlatımları, posterler ve broşürler kullanılmış olsa da bilginin aktarımı amacıyla ideal bir yöntem tanımlanmamıştır. ${ }^{9,12,15}$ Bu çalışmada da eğitim-öğretim faaliyetlerini aksatmadan yapılabilmesi, hızlı ve ekonomik bir yöntem olmasından dolayı broşür kullanımı tercih edilmiştir. Çalışmamızda broşür kullanmamızın bir diğer sebebi ise hem kişiye özel bilgi aktarıcı bir yöntem olması hem de broşürlerin gerekli hallerde tekrar ulaşılarak bilginin hatırlanması avantajını barındırmasıdır. Meydana gelebilecek yaralanmalardan korunma ve yaralanma sonrası olabilecek riskler hakkında toplumun bilgilendirilmesi amacıyla öncelikle bilgi sahibi olmaları gereken ebeveyn ve öğretmenlere yönelik olarak çalışmalar yapılsa da henüz bu konu toplum sağlığı kampanyalarında yüksek önceliğe sahip değildir. ${ }^{1-3}$ Konu ile ilgili birçok çalışmada öğretmenlerin TDY hakkındaki bilgi düzeylerinin çok düşük olduğu görülmüştür. ${ }^{6-9}$ Ülkemizde yapılmış olan az sayıdaki çalışmada da durum benzer şekildedir. ${ }^{10,11} \mathrm{Bu}$ çalışmaya dahil olan öğretmenlerin TDY hakkındaki bilgi düzeyleri de konu hakkında daha önce yapılmış olan çalışmalara benzer şekilde oldukça düşük olarak bulunmuştur.

Öğretmenlerin TDY hakkındaki bilgi düzeylerini ölçmeyi hedefleyen birçok çalışmada, yaş ve cinsiyetin öğretmenlerin bilgi düzeyi ve tutumlarını etkilemesi ile ilgili farklı veriler elde edilmektedir.9,16,17 Bu çalışmada kadın öğretmenlerin bilgi seviyesinin yüksek olmasının nedeni kadınların annelik duyguları ve bakıcı rolleri ile ilişkilendirilebilir. Illerleyen yaş ve meslekte hizmet süresi ile artan bilgi düzeyinin ise artan özgüven ve tecrübeyle ilişkili olduğu düşünülmektedir.

Dünya genelinde ve ülkemizde yapılan çalışmalar, öğretmenlerin büyük bir kısmının ilk yardım kursu almadığını belirtmektedir. Bu kursların TDY'de ilk yardım konusunu içerme oranı ise maalesef daha da düşüktür. ${ }^{7,10,16,18}$ Benzer şekilde bu çalışmada da katılımcı ilkokul öğretmenlerinin \%36,70'i ilk yardım kursu aldıklarını belirtmiştir, fakat sadece \%3'ünün TDY'de acil durum yönetimi konusunda eğitim aldığı tespit edilmiştir. Aynı zamanda TDY'de 
acil durum yönetimi kursuna katılanların bilgi düzeyleri oldukça düşük olarak bulunmuş ve katılmayanlarla aralarında anlamlı bir farklılık saptanmamıştır. Bu sonuçlar da açıkça göstermektedir ki TDY hakkındaki eğitimler daha yaygın ve etkin hale getirilmelidir. Ayrıca bu kursların belirli zaman aralıklarıyla tekrarlanıp konu hakkındaki bilgi seviyesi olabildiğince yükseltilmelidir. TDY'de acil müdahale yöntemi ile ilgili öğretmenlerin bilgi düzeylerini ölçmeyi hedeflerken; öğretmenlerin TDY hakkındaki tutum ve kişisel tecrübelerini değerlendirmek de onlarda bu konuda bir farkındalık oluşturmak açısından çok önemlidir. Bu amaçla 2. bölümde öğretmenlerin TDY karşısındaki tutumları değerlendirilmiş ve alınan cevaplar Raof ve ark.'nın ${ }^{6}$ yapmış olduğu çalışmayla benzer bulunmuştur. Bu bilgilere paralel olarak öğretici broşürlerin dağıtılmasını takiben alınan tüm cevaplarda anlamlı bir artış meydana gelmiştir. Bu değişiklik bilgi düzeyiyle birlikte artan farkındalık ve sorumluluk duygularıyla açıklanabilir.

Öğretmenlerin daha önce dental yaralanma görüp görmediğini sorgulamak da TDY'nin yaygınlığının değerlendirilmesiadına önemli kriterlerden birisidir. Hong Kong, Singapur, İzmir, İstanbul ve Porto'da yapılan çalışmalarda bu oranın sırasıyla $\% 28^{29}, \% 24^{12}, \% 50^{8}, \% 35,8^{19}$ ve $\% 23^{20}$ olduğu belirtilmektedir. Çalışmamızda ise test sonuçları değerlendirildiğinde elde edilen veriler, katıımcı öğretmenlerin \%60'ının önceden TDY olguları ile karşılaştığını ortaya koymaktadır. Benzer çalışmalara göre daha yüksek olduğu gözlenen bu sonuç; sık sık TDY meydana gelme olasılığı olan okullarda, öğretmenlerin ve tüm okul personelinin TDY'de acil yönetimi hakkında bilgi sahibi olmaları gerektiği düşüncesini güçlendirmektedir.

Konu ile ilgili yapılan çalışmalarda katıımcı öğretmenlerin, karşılaştıkları yaralanmanın türü de sorgulanmıştır. Çalışmamızda da daha önce yapıımış çalışmalara ${ }^{6.8}$ benzer şekilde TDY tecrübesi olan 735 öğretmenin verdiği cevaplar doğrultusunda en çok karşılaşılan yaralanmanın \%36,7 ile mine-dentin kırığı olduğu tespit edilmiştir.

Subramaniam ve ark. ${ }^{21}$ yaptıkları çalışmada katılımcı öğretmenlerin yaklaşık yarısının TDY sonrası ilk müracaat edecekleri birim olarak "Diş Hastanesi" seçeneğini işaretlediklerini belirtmektedir. ${ }^{21}$ Fakat Mohandas'ın çalışmasına katılan öğretmenlerin yalnızca $\% 12,9^{\prime}$ u olası bir yaralanma anında diş hastanesine başvuracaklarını bildirmiştir.7 Diyarbakır il merkezinde uyguladığımız çalışmamızda ise öğretmenlerin \%48,6'sı "Diş Hastanesi" seçeneğini işaretlemişlerdir. Bu sonucun sosyo-ekonomik açıdan kamuda verilen sağlık hizmetlerinin daha fazla tercih edilmesi ile ilişkili olduğunu düşünmekteyiz.

Anketin 4. bölümünde öğretici broşürün etkisiyle öğretmenlerin TDY hakkındaki bilgi düzeyi incelenmiştir. Konküzyon-sublüksasyon, kron kırıkları, lüksasyon yaralanmaları ve avülsiyon yaralanmaları hakkında hazır- lanan vakaların katıımcı öğretmenler tarafından daha iyi anlaşılabilmesi için broşürde kullanılan fotoğraf ve grafikler özenle seçilmiştir. Broşür özellikle yaralanma sırasında dişlerin prognozunu önemli ölçüde etkileyen, yapılması gereken basit ama etkin müdahaleleri içermektedir. Bu bilgilerin ışığı altında 4.bölümdeki tüm vaka değerlendirmelerinde, birçok çalışmayla benzer şekilde, ${ }^{7,9,10}$ bilgi düzeyinde anlamlı bir artış gözlemlenirken; sadece süt dişi avülsiyonuna yönelik yöneltilen soru için anlamlı bir farklıık gözlenmemiştir. Hazırlanan broşürde anlatılanların süt dişleri için geçerli olmadığı ifadesinin konu hakkında anlamlı bir değişim oluşturmaya yeterli olmadığı kanaatine varılmıştır. Bu konuda yapılacak çalışmalarda daimi ve süt dişi yaralanmalarında uygulanması gereken tedavilerin farklı olduğunun daha etkili biçimde belirtilmesi gerektiği düşüncesindeyiz.

Çalışmamızın sonucunda TDY hakkındaki birçok konuda katılımcı öğretmenlerin bilgi seviyelerinin artması memnuniyet vericidir. Fakat bu bilgi seviyesi artışı kısa dönemde meydana gelmiş olup, çalışmanın etkinliğinin uzun dönem araştırmalarla da incelenmesine intiyaç vardır. Ülkemizde öğretmenlerin konu hakkındaki bilgi seviyelerini artırmayı amaçlayan daha fazla sayıda çalışma yapılması gerektiğini düşünmekteyiz.

\section{KAYNAKLAR}

1. Kuşçu ÖÖ, Sandallı N, Çağlar E. Çocuklarda diş travmaları. 7Tepe Klinik 2011; 3: 6-14.

2. Arısu HD. Travmatik Dental Yaralanmaları Önlemek Için Neler Yapılmalı? Turkiye Klinikleri J Dental Sci-Special Topics 2014; 5: 21-26.

3. Altay N, Güngör H. A retrospective study of dentoalveolar injuries of children in Ankara, Turkey. Dent Traumatol 2001; 1: 201-204.

4. Oikarinen K, Kassilla O. Causes and types of traumatic tooth injuries treated in a public dental health clinic. Endod Dent Traumatol 1987; 3: 172-177.

5. Skaare $A B$, Jacobsen I. Etiological factors related to dental injuries in Norwegians aged 7-18 years. Dent Traumatol 2003; 19: 30-48.

6. Raof M, Zaherara F. Elementary school staff knowledge and attitude with regard to first-aid management of dental trauma in Iran: a basic premise for developing future intervention. Dent Traumatol 2011; 28: 10-18.

7. Mohandas U, Chandan GD. Knowledge, attitude and practice in emergency management of dental injury among physical education teachers: a survey in Bangalore urban schools. J Indian Soc Pedod Prev Dent 2009; 27: 242-248.

8. Sae-Lim V, Lim LP. Dental trauma management awareness of Singapore pre-school teachers. Dent Traumatol 2001; 17: 71-76.

9. Chan AW, Wong TK, Cheung GS. Lay knowledge of 
physical education teachers about the emergency management of dental trauma in Hong Kong. Dent Traumatol 2001; 17: 77-85.

10. Arikan V, Sönmez H. Knowledge level of primary school teachers regarding traumatic dental injuries and their emergency management before and after receiving an informative leaflet. Dent Traumatol 2012; 28: 10-17.

11. Caglar E, Ferreira L, Kargul B. Dental trauma management knowledge among a group of teachers in two south European cities. Dent Traumatol 2005; 21: 258-262.

12. Lieger $\mathrm{O}$, Graf $\mathrm{C}$, El-Maaytah M, Von Arx T. Impact of educational posters on the lay knowledge of school teachers regarding emergency management of dental injuries. Dent Traumatol 2009; 25: 406-412.

13. Fakhruddin KS, Lawrence HP, Kenny DJ, Locker D. Etiology and environment of dental injuries in 12-to-14year-old Ontario schoolchildren. Dent Traumatol 2008; 24: $305-308$

14. Locker D. Prevalence of traumatic dental injury in grade 8 children in six Ontario communities. Can J Public Health 2005; 96: 73-76.

14. Al-Asfour A, Andersson L, Al-Jame Q. School teachers' knowledge of tooth avulsion and dental first aid before and after receiving information about avulsed teeth and replantation. Dent Traumatol 2008; 24: 43-49.

15. Al-Jundi SH, Al-Waeili H, Khairalah K. Knowledge and attitude of Jordanian school health teachers with regards to emergency management of dental trauma. Dent Traumatol 2005; 21: 183-187.

16. Feldens EG, Feldens CA, Kramer PF, Da Silva KG, Munari CC, Brei VA. Understanding school teacher's knowledge regarding dental trauma: a basis for future interventions. Dent Traumatol 2010; 26: 158-163.

17. Blakytny C, Surbuts $C$, Thomas A, Hunter ML. Avulsed permanent incisors: knowledge and attitudes of primary school teachers with regard to emergency management. Int J Paediatr Dent 2001; 11: 327-332.

18. Mesgarzadeh AH, Shahamfar M, Hefzollesan A. Evaluating knowledge and attitudesof elementary school teachers on emergency management of traumatic dentalinjuries: a study in an Iranian urban area. Oral Health Prev Dent 2009; 7: 297-308.

19. Ersin N, Önçağ Ö. İlkokul öğretmenlerinin dental travmalarla ilgili bilgi düzeylerinin değerlendirilmesi. Ondokuz May Üni Derg 2011; 12: 63-68.

20. Subramaniam R, Simpy M. Knowledge of upper primary and secondary school physical education instructors in Davangere city, India, about emergency management of dental trauma. Journal of Education and Ethics in Dentistry 2011: 10-19.
Ek 1. Çocuklarda travmatik diş yaralanmaları ve acil müdahale hakkında ilkokul öğretmenlerine yönelik hazırlanan anket formu

\section{BÖLÜM I: KişiSEL BILGILER}

\section{Cinsiyetiniz}

a. Erkek b. Kadın

2. Yaşınız
a. $22-30$
b. $30-40$
c. $40>$

\section{Meslekte hizmet süreniz}
a. 1-5
b. 6-10
c. $11>$

4. Daha önce ilk yardım kursu aldınız mı?
a. Evet
b. Hayır

5. Yukarıdaki soruya cevabınız evet ise aldığınız kurs 'travmatik diş yaralanmalarında acil durum' konusunu içeriyor muydu?

a. Evet b. Hayır

\section{BÖLÜM II: TUTUMLAR}

Aşağıdaki ifadelerden size en uygun olanı işaretleyiniz.

1. Travmatik diş yaralanmaları acil müdahale gerektiren bir durum değildir.
a. Katılıyorum
b. Katılmıyorum
c. Kararsızım

2. Travmatik diş yaralanmalarında müdahale zamanlaması dişin iyileşme sürecinde çok önemlidir.
a. Katılıyorum
b. Katılmıyorum
c. Kararsızım

3. Bir öğretmen travmatik diş yaralanmalarının sonrasındaki müdahaleden sorumlu değildir.
a. Katılıyorum
b. Katılmıyorum
c. Kararsızım

4. 'Travmatik diş yaralanmalarında acil müdahale' öğretmenlere verilen eğitim konularından biri haline getirilmelidir.
a. Katıliyorum
b. Katılmıyorum
c. Kararsızım

5. Öğretmenler verilecek eğitimlerle daha başarılı müdahalelerde bulunabilir. Böylece hekimlere daha etkili şekilde yardımcı olabilirler.
a. Katılıyorum
b. Katılmıyorum
c. Kararsızım

\section{BÖLÜM III: KişiSEL TECRÜBE VE KENDINi DEĞERLENDIRME}

1. Daha önce diş yaralanması gördünüz mü?
a. Evet
b. Hayır

2. Yukarıdaki soruya cevabınız evet ise karşılaştığınız ne tür bir yaralanmaydı?

a. Küçük bir kıııtı

b. Diște kırık yoktu fakat diş sallanıyordu

c. Dişin özünden gelen, kanaması olan büyük bir kırıktı

d. Diş yuvasında yer değiştirmişti

e. Diş tamamen yuvasından çıkmıştı

3. Travmatik diş yaralanmalarında ilk olarak hangi birime müracaat edersiniz?

a. Herhangi bir hastaneye 
b. Diş Hekimliği Fakültesine

c. Diş Hastanesine

d. Diş Hekimi Muayenehanesine

BÖLÜM IV: TRAVMATIK Diş YARALANMALARINDA BILLGI DÜZEYI

\section{VAKA I.}

10 yaşındaki öğrenciniz arkadaşıyla çarpıştı. Dişlerde gözle görülen herhangi bir yaralanma yok ya da çok hafif bir kanama mevcut. Bunun dışında herhangi bir yaralanma
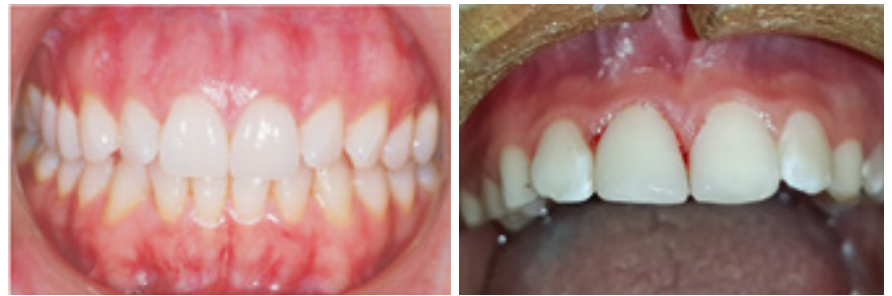

$\star$ Böyle bir durumda ne yaparsınız?

a. Dişte kırık olmadığı için herhangi bir şey yapmam

(0 puan)

b.Veliyi bilgilendirip diş hekimine yönlendiririm

(2 puan)

c.Ne yapılacağını bilmiyorum

(0 puan)

\section{VAKA II.}

9 yaşındaki öğrenciniz koşarken düştü ve üst ön dişlerinden biri kırıldı. Dişin özünden (pulpa) gelen bir kanaması var/yok. Bunun dışında herhangi bir yaralanma ve bilinç kaybı yok.

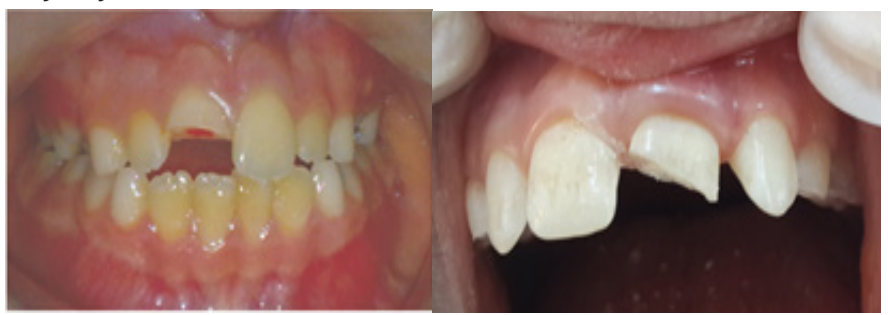

*Sizce böyle bir diş kırığında ayrılan parçanın bulunması gerekir mi?

a.Evet, (2 puan)

b. Hayır (0 puan)

*Böyle bir durumda ne yaparsınız?

a. Ağzını çalkalamasını söyleyip okuldan sonra diş hekimine gitmesi gerektiğini anlatırım (0 puan)

b. Veli ile iletişime geçip acil bir şekilde diş hekimine yönlendiririm (2 puan)

c. Kırık parçayı bulduktan sonra acil bir şekilde diş hekimine yönlendiririm (4 puan)

d. Ne yapılacağını bilmiyorum (0 puan)

\section{VAKA III.}

10 yaşındaki öğrenciniz yüzünü sıraya çarptı ve üst ön dişlerinden birisi damağa doğru yer değiştirdi. Bunun dışında herhangi bir yaralanma ve bilinç kaybı yok.

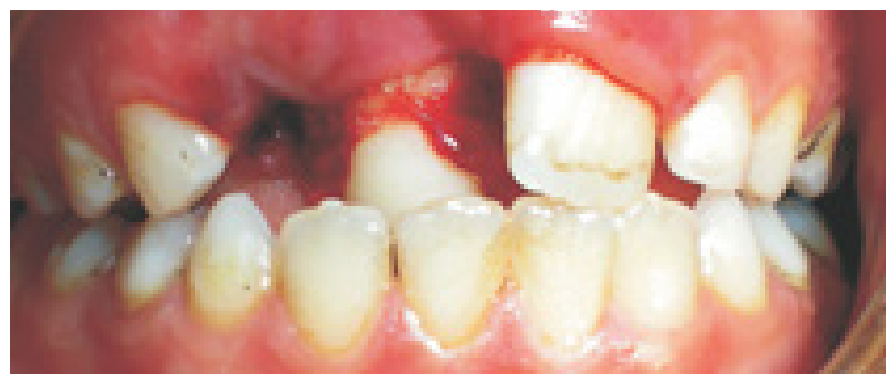

*Böyle bir durumda ne yaparsınız?

a. Dişi ağrıdığında diş hekimine gitmesini söylerim.(0 puan)

b. Etkilenen dişi parmağımla nazikçe yerine tekrar yerleştirmeyi dener ve diş hekimine yönlendiririm (4 puan)

c. Dişe dokunmadan hızlıca diş hekimine yönlendiririm (2 puan)

d. Ne yapılacağını bilmiyorum (0 puan)

\section{VAKA IV.}

9 yaşında öğrenciniz merdivenlerden düştü, üst ön dişlerinden biri yerinden tamamen çıktı. Dişin yuvasından gelen bir kanama var. Bunun dışında herhangi bir yaralanma ve bilinç kaybı yok.

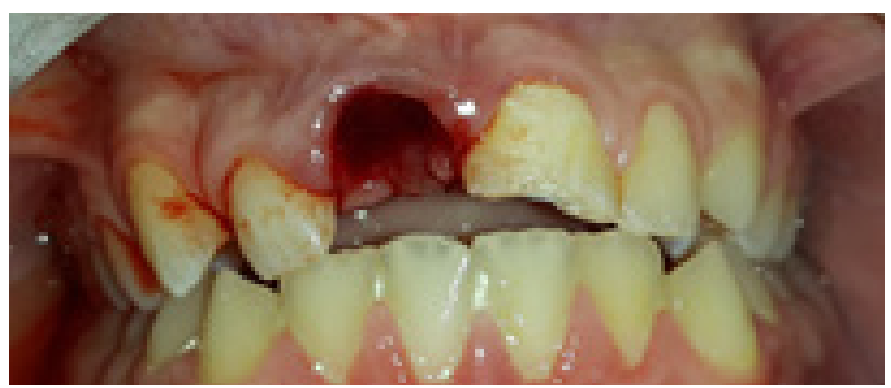

\section{*Böyle bir durumda ne yaparsınız?}

a.Temiz bir gazlı bezle yaranın üzerine bastırarak kanamayı durdururum (0 puan)

b.Veliyi bilgilendirip çocuğu okuldan sonra diş hekimine götürmeleri gerektiğini anlatırım (0 puan)

c.Dişi bulmaya çalışırım (4 puan)

*Dişi bulursanız neresinden tutarsınız?

a. Kökünden (0 puan)

b. Görünen yüzeyinden (2 puan)

c. Bunun önemli olduğunu düşünmüyorum(0 puan)

*Dişi yerine yerleştirebileceğinizi düşünüyor musunuz?

a. Evet ( 2 puan)

b. Hayır (0 puan)

*Dişi tekrar yerine yerleştirmeden önce hangi temizleme prosedürünü uygularsınız?

a. Hiçbir temizleme işlemi yapmadan diși yerine yerleştiririm (0 puan)

b. Dişi akan su altında ovalamadan temizler ve yerine yer- 
leştiririm (4 puan)

c. Dişi yeni bir diş fırçasıyla iyice temizleyip yerine yerleştiririm (0 puan)

*Eğer dişi yerine yerleştiremeyecekseniz; dişin aşağıdaki koşullardan hangisiyle diş hekimine ulaşmasını sağlarsınız?

a. Temiz bir mendil içinde (0 puan)

b. Gazlı bez içinde (0 puan)

c. Çocuğun kendi tükürüğü içinde (2 puan)

d. Su dolu bir kap içinde (1 puan)

e. Dezenfektan bir solüsyon içinde (0 puan)

f. Taze süt içinde (2 puan)

*Sizce diş yerinden çıtıktan sonra ne kadar zaman içinde yerine yerleştirilmelidir?
a. Hemen (4puan)
b. 1 saat içinde ( 2 puan)
c. Ertesi gün (0 puan)
d. Bilmiyorum (0 puan)

* Süt ve daimi dişleri birbirinden ayırt edebilir misiniz?
a. Evet ( 2 puan)
b. Hayır (0 puan)

* Süt dişi yerinden çıktığında yerine yerleştirir misiniz?

a. Evet (0 puan

b. Hayır (2 puan) 